\title{
PENGANGGARAN KEUANGAN MADRASAH
}

\section{Nurhidayah}

MTs Pesantren Pembangunan Cigaru

Cigaru, Salebu, Kec. Majenang, Kabupaten Cilacap, Jawa Tengah 53257

Email: hidayah.rido@gmail.com

\begin{abstract}
ABSTRAK
Penelitian ini bertujuan untuk mengetahui penganggaran keuangan pendidikan pada Madrasah Tsanawiyah Pesantren Pembangunan Majenang Kabupaten Cilacap. Metode pengumpulan data yang digunakan adalah observasi, wawancara dan studi dokumentasi. Teknik analisis data yang digunakan adalah analisis, kritis. Berdasarkan metode tersebut diperoleh temuan penelitian, yaitu dalam prosedur penganggaran keuangan madrasah secara umum belum semuanya diterapkan pada proses penyusunan anggaran keuangan madrasah. Hal tersebut ditandai dengan belum adanya tanda tangan pada Rencana Kegiatan dan Keuangan Madrasah (RKAM) oleh kepala madrasah dan tidak adanya revisi pada usulan anggaran yang pada kenyataannya dalam mengesahkan anggaran madrasah mengadakan rapat pleno bersama wali murid yang tidak semuanya setuju dengan usulan anggaran tersebut. Oleh karena itu, untuk membudayakan pengelolaan dalam penganggaran keuangan sesuai dengan prosedur harus mampu menyusun anggaran sesuai dengan kebutuhan dan mempertimbangkan prosedur penganggaran keuangan.
\end{abstract}

Kata Kunci: Penganggaran, Madrasah, Keuangan

\section{ABSTRACT}

This research aims to recognize the budgeting of education finance at Madrasah Tsanawiyah Pesantren Pembangunan Majenang Kabupaten Cilacap. The Methods used in this research is collection used were observation, interview and dokumentation. Data analysis technique used is critical analysis. The result obtained are, namely the procedure of financial accounting of madrasah in general not yet applied ti the process of preparing the budget of madrasah. thus marked by the absence of signature on the Madrasah Activity and Budget Plan (RKAM) by the head of the madrasah and the absence of revisions to the budget proposal which in fact approving the madrasah budget held a plenary meeting with guardians who did not all agree with the budget proposal. Therefore, to cultivate financial management and budgeting in accordance with the procedure should be able to arrabfe the budget according needs and consider financal budgeting procedures.

Keywords: Budgeting, Madrasah, Accounting 


\section{PENDAHULUAN}

Terdapat dua agenda penting pemerintah berkenaan dengan bidang pendidikan, yaitu: peningkatan mutu Pendidikan Nasional dan pemerataan kesempatan memperoleh pendidikan bagi semua lapisan masyarakat Indonesia. Dalam rangka mewujudkan agenda tersebut, pemerintah melalui beberapa kebijakannya berupaya mewujudkan pendidikan yang berkualitas, di antaranya adalah kebijakan pendanaan untuk meningkatkan mutu pendidikan Indonesia. Dalam pasal 31 ayat (4) Undang-Undang Dasar Negara RI tahun 1945 dinyatakan "Negara memprioritaskan anggaran pendidikan sekurangkurangnya 20 persen dari anggaran pendapatan dan belanja negara (APBN) serta anggaran pendapatan dan belanja daerah (APBD) untuk memenuhi kebutuhan penyelenggaraan pendidikan nasional" (Fahrurrozi, 2012: 224).

Penerapan peraturan dan sistem manajemen keuangan yang baku dalam lembaga pendidikan tidak dapat disangkal lagi. Permasalahan terjadi di dalam lembaga terkait manajemen keuangan pendidikan diantaranya sumber dana yang terbatas, pembiayaan program yang serampangan, tidak mendukung visi, misi dan kebijakan sebagaimana tertulis di dalam rencana strategis lembaga pendidikan. (Abubakar dan Taufani C. Kurniatun, 2015: 256)

Terkait dengan manajemen keuangan madrasah, sumber pendapatan dari Madrasah Tsanawiyah Pesantren Pembangunan Cigaru, Majenang, Cilacap diperoleh dari wali murid melalui komite madrasah yang berupa Sumbangan Operasional Pendidikan (SOP) tiap bulan, Infak jariyah satu tahun sekali atau yang biasa dikenal dana pembangunan madrasah (Surat Pemberitahuan Hasil Rapat Komite dan Ulangan Akhir Semester Gasal, MTs.8/13/PP/.005/118/2016), dan bantuan operasional sekolah dari pemerintah (BOS) pusat (Rencana Kegiatan dan Anggaran Madrasah RKAM MTs Pesantren Pembangunan Majenang Tahun Pelajaran 2015-2016).

Biaya SOP tiap bulan pada tahun 2016 di MTs Pesantren Pembangunan Majenang yaitu Rp 30.000. Hal tersebut diketahui pada laporan pertanggungjawaban SOP MTs Pesantren Pembangunan Majenang Tahun Pelajaran 2015-2016. Sedangkan biaya pada tahun pelajaran 2016-2017 yaitu sebesar Rp 35.000. Biaya Jariyah untuk tahun 2016-2017 yaitu Rp 350.000 untuk kelas 7, Rp 225.000 untuk kelas 8, dan Rp 150.000 untuk kelas 9 Hal tersebut tercantum pada surat pemberitahuan hasil rapat pleno Komite dan UAS pada tanggal 21 November 2016 (MTs.8/13/PP.00.5/118/2016).

Bantuan Operasional Sekolah (BOS) di dapatkan dalam triwulanan atau empat kali dalam satu tahun. Dalam Rencana Kegiatan dan Anggaran Madrasah MTs Pesantren Pembangunan Cigaru, Majenang Tahun pelajaran 2015/2016 jumlah penerimaan dana nya yaitu sebesar Rp 1.130.005.000. uraian dana nya yaitu Bantuan Operasional Sekolah Rp 735.000.000, kemudian Pendapatan Asli Sekolah antara lain: SPP sebesar Rp 253.080.000 dan Infak Jariyah sebesar Rp 141.925.000 (RKAM MTs Pesantren Pembangunan Majenang Tahun 2015/2016).

Sedangkan jumlah pengeluarannya sebesar $R p$ 1.130.005.000, pengluaran digunakan untuk program madrasah dan belanja lainnya. Program madrasah yaitu program pengembangan standar pendidikan. Uraiannya adalah Rp 61.428.000 untuk pengembangan kompetensi lulusan, Rp 500.000 untuk pengembangan Kurikulum/KTSP (standar isi), Rp 107.060.000 untuk 
pengembangan proses pembelajaran (standar proses), Rp 7.400.000 untuk pengembangan pendidik dan tenaga kependidikan, $\mathrm{Rp} 70.200 .000$ untuk pengembangan sarana dan prasarana madrasah, Rp 35.460 .000 untuk pengembangan dan implementasi manajemen madrasah, Rp 306.351 .600 untuk Pengembangan dan panggilan sumber dana pendidikan (standar Pembiayaan) dan Rp 45.212.000 untuk pengembangan dan Implementasi sistem penilaian. Kemudian untuk belanja lainnya sebesar Rp 494.393.300 (RKAM MTs Pesantren Pembangunan Majenang Tahun 2015/2016).

Laporan pertanggung jawaban SOP tahun 2015/2016 berjumlah sebesar Rp 930.693.986 pada kolom pemasukan dan Rp 919.674.986 pada kolom pengeluaran. Dari data tersebut dapat diketahui bahwa madrasah memiliki saldo lebih sebesar Rp 11.019.000.

Madrasah Tsanawiyah Pesantren Pembangunan berbeda dengan madrasah lain, yang biasanya jumlah anggaran sama dengan jumlah pengeluaran atau bahkan kekurangan dana, justru madrasah ini memiliki saldo lebih yang berarti pengalokasian dana saat penganggaran keuangan madrasah terserap dengan baik dan sesuai dengan kebutuhan madrasah.

Studi tentang penganggaran keuangan madrasah, khususnya Madrasah Tsanawiyah Pesantren Pembangunan Majenang menjadi sangat penting dan aktual manakala dikaitkan dengan terbatasnya sumber dana yang tersedia serta rendahnya kekuatan ekonomi pemerintah dan masyarakat untuk membiayai pendidikan. Kecenderungan ini menuntut adanya kemampuan penganggaran keuangan madrasah yang alokasi dananya sesuai dengan kebutuhan.

Penelitian ini bertujuan untuk mengetahui Proses Penyusunan Rencana Kegiatan dan Anggaran Madrasah (RKAM) Madrasah Tsnawiyah Pesantren Pembangunan Majenang dan mengetahui aspek-aspek yang perlu dikembangkan dalam prosedur penganggaran keuangan madrasah, sehingga pada gilirannya alokasi dana pendidikan pada Madrasah Tsanawiyah Pesantren Pembangunan terserap dengan baik.

\section{METODE}

Penelitian ini menggunakan pendekatan kualitatif yang bertujuan untuk memperoleh informasi mengenai penganggaran keuangan madrasah (studi kasus di MTs Pesantren Pembangunan Majenang). Rancangan penelitian dalam penelitian manajemen madrasah berbasis lingkungan hidup (studi kasus di MTs Pesantren Pembangunan Majenang) ini menggunakan rancangan studi kasus.

Penelitian ini dilakukan di MTs Pesantren Pembangunan Majenang yang terletak di Cigaru, Salebu, Kec. Majenang, Kabupaten Cilacap, Jawa Tengah. Dalam penelitian kualitatif yang menjadi instrumen penelitian adalah peneliti itu sendiri. Kehadiran peneliti di lapangan untuk melaksanakan penelitian ini menjadi prioritas dalam penelitian ini. Kehadiran peneliti di lokasi penelitian yaitu untuk mencari informasi dan data yang terkait dengan penelitian. Selanjutnya peneliti melakukan pendekatan terhadap informan agar memudahkan peneliti dalam mendapatkan informasi yang berkaitan dengan penelitian ini. Sebelum melakukan penelitian di lokasi penelitian maka peneliti menyiapkan berbagai alat yang dapat menunjang penelitian. Dalam proses 
penelitian tersebut, peneliti membawa alat perekam hasil wawancara, kamera untuk mengambil gambar dokumentasi dan buku catatan peneliti. Penelitian diawali dengan melakukan wawancara dengan informan penelitian. Di samping itu peneliti juga melakukan observasi dan dokumentasi terkait fokus penelitian.

Penelitian mengenai manajemen madrasah berbasis lingkungan hidup (studi kasus di MTs Pesantren Pembangunan Majenang) ini peneliti mengklasifikasikan sumber data dalam penelitian ini yaitu (a) Person (sumber data berupa orang) yaitu Wakil Kepala Sekolah (b) Place (sumber data berupa tempat) yaitu MTs Pesantren Pembangunan Majenang; (c) Paper (sumber data berupa kertas) yaitu Dokumen berupa profil sekolah dan dokumen yang berkaitan dengan penelitian.

Teknik pengumpulan data dalam penelitian ini menggunakan teknik wawancara, observasi dan dokumentasi. Teknik wawancara yang digunakan yaitu wawancara semi terstuktur untuk menemukan permasalahan secara lebih terbuka, dimana pihak yang diajak wawancara dimintai pendapat, dan ideidenya. Adapun instrumen pengumpulan data dalam teknik wawancara penelitian kualitatif ini berupa pedoman wawancara. Pada proses wawancara peneliti akan membuat pedoman wawancara, melakukan rekaman wawancara, dan membuat catatan selama wawancara.

Teknik analisis data menggunakan reduksi data, penyajian data dan verifikasi data. Reduksi data berarti merangkum, memilih hal-hal pokok, memfokuskan pada hal-hal yang penting. Dengan demikian data yang telah direduksi akan memberikan gambaran yang lebih jelas. Setelah melakukan reduksi data maka selanjutnya melakukan penyajian data yaitu dengan menyajikan data yang sudah direduksi ke dalam bentuk teks, atau bisa juga dengan grafik, matrik, dan lain sebagainya.

Teknik keabsahan data menggunakan uji kredibilitas, transferabilitas, dependabilitas, konfirmabilitas. Dalam melakukan uji kredibilitas peneliti menggunakan triangulasi sumber dan teknik. Di dalam pengujian transferabilitas peneliti membuat laporan dengan memberikan uraian yang rinci, jelas, sistematis, dan dapat dipercaya. Pengujian dependabilitas ini dapat dilakukan oleh tim pembimbing dan penguji tentang benar tidaknya peneliti melakukan penelitian langsung ke lokasi penelitian. Dalam uji dependabilitas ini pembimbing melakukan audit keseluruhan aktivitas peneliti dalam melakukan penelitian.

\section{HASIL DAN PEMBAHASAN}

Pendidikan memiliki tujuan yang tercantum dalam UU No. 20 Tahun 2003 tentang Sistem Pendidikan Nasional. Tujuan ini tentu saja meliputi pelbagai pendidikan yang ada di Indonesia baik itu pendidikan formal maupun nonformal. Setiap lembaga pendidikan memiliki tujuan masing-masing yang menjadikan manajemen sebagai fungsi dalam mencapai tujuannya secara efektif. Dalam Peraturan Pemerintah No. 19 tahun 2005 telah menetapkan standar-standar nasional pendidikan yang salah satunya yaitu tentang standar pembiayaan pendidikan (Jaja, 2013: 91).

Salah satu komponen yang penting yaitu manajemen keuangan/pembiayaan pendidikan. Dana memainkan peran penting dalam pendidikan pada tiga area: pertama, ekonomi pendidikan dalam kaitannya 
dengan pengeluaran masyarakat secara keseluruhan; kedua, keuangan sekolah kaitannya dengan kebijakan sekolah untuk menterjemahkan uang terhadap layanan kepada peserta didik; dan ketiga, pajak administrasi bisnis sekolah yang harus diorganisir secara langsung berkaitan dengan tujuan kebijakan. Pusat perhatian mendasar dari konsep ekonomi adalah bagaimana mengalokasikan sumber-sumber terbatas untuk mencapai tujuan yang beraneka ragam mungkin tak terhingga. (Mulyasa, 2013: 195)

Pembiayaan pendidikan, merupakan aktivitas yang berkenaan dengan perolehan dana (pendapatan) yang diterima dan bagaimana penggunaan dana tersebut dipergunakan untuk membiayai seluruh program pendidikan yang telah ditetapkan. Seperti, dikemukakan oleh Thomas John (1985: 20), yaitu bagaimana uang diperoleh untuk membiayai lembaga pendidikan, dari mana sumbernya, dan untuk apa dibelanjakan serta siapa yang membelanjakan (Akdon, 2015: 23).

Manajemen Keuangan Sekolah (pembiayaan sekolah) pada dasarnya merupakan bagian dari pembiayaan pendidikan yang tercermin dari anggaran yang ditetapkan oleh sekolah, sehingga untuk bidang ini diperlukan penanganan yang serius, agar dicapai suatu proses pengelolaan yang efektif dan efisien dalam mengelola anggaran serta program-program yang dibiayai dalam mencapai tujuan pendidikan sekolah (Uhar, 2010: 270).

Menurut Peraturan Pemerintah No. 19 Tahun 2005 tentang Standar Pembiayaan, yang dimaksud dengan standar pembiayaan adalah standar yang mengatur komponen dan besarnya biaya operasi satuan pendidikan yang berlaku selama satu tahun (Pasal, ayat 10). Pembiayaan pendidikan terdiri atas biaya investasi, biaya operasi dan biaya personal (Pasal 62, ayat 1) (Fattah, 2016: 93).

Biaya dalam pendidikan meliputi biaya langsung (direct cost) dan biaya tidak langsung (indirect cost). Biaya langsung terdiri dari biaya-biaya yang dikeluarkan untuk keperluan pelaksanaan pengajaran dan kegiatan belajar siswa berupa pembelian alat-alat pelajaran, sarana belajar, biaya transportasi, gaji guru, baik yang dikeluarkan oleh pemerintah, orang tua, maupun siswa sendiri. Sedangkan biaya tidak langsung berupa keuntungan yang hilang (earning forgone) dalam bentuk biaya kesempatan yang hilang (opportunity cost) yang dikorbakan oleh siswa selama belajar (Fattah, 2012: 23).

Anggaran menyediakan konteks bagi proses perencanaan atau seperangkat kegiatan yang berdasarkan jenis manusianya dan dapat diterapkan. Selanjutnya anggaran menjadi dokumen yang merangkum keputusan-keputusan rencana. Dalam hal ini anggatan bertindak sebagai alat untuk menjamin kehati-hatian dan kejujuran dalam mengutus dana publik. Anggaran merupakan dokumen publik yang bisa saja dipelajari oleh orang di luar sistem (Fattah, 2016: 56).

Menurut Nanang Fattah (2016: 55) Salah satu komponen manajemen keuangan yaitu prosedur penyusunan anggaran dan akan disebutkan sebagai berikut: (1) Mengidentifikasi kegiatan-kegiatan yang akan dilakukan selama periode anggaran; (2) Mengidentifikasi sumber-sumber yang dinyatakan dalam uang, jasa dan barang; (3) Semua sumber-sumber dinyatakan dalam uang, jasa dan barang; (4) Semua sumber dinyatakan dalam bentuk uang sebab anggaran pada dasarnya merupakan pernyataan finansial; (5) Menyusun 
usulan anggaran untuk memperoleh persetujuan dari pihak yang berwenang; (6) Melakukan revisi ulang anggaran; (7) Persetujuan usulan anggaran; (8) Pengesahan anggaran.

Sumber pembiayaan untuk sekolah terutama sekolah negeri berasal dari pemerintah yang umumnya terdiri dari dana rutin, yaitu gaji serta biaya operasional sekolah dan perawatan fasilitas (OPF), serta dana yang berasal dari masyarakat, baik yang berasal dari orang tua siswa, dan sumbangan dari masyarakat luas/dunia usaha (Fattah, 2016: 42). Sumber-sumber keuangan sekolah dapat bersumber dari: orang tua, pemerintah pusat, pemerintah daerah, swasta, dunia usaha, dan alumni. Pemerintah merupakan penanggung dana terbesar di antara yang lain (sekitar 70\%). Selanjutnya orangtua murid (10-24\%), masyarakat (sekitar 5\%), dan yang terakhir pihak lain, baik berbentuk hibah maupun pinjaman (Rusdiana, 2015: 226).

Dana hasil dari berbagai sumber akan digunakan untuk biaya operasional proses pendidikan di satuan pendidikan maupun lembaga/yayasan pendidikan. Perhitungan pengeluaran biaya pendidikan di sekoalah dapat dikategorikan kedalam beberapa item pengeluaran, (Skripsi Septi Marliyani) sebagai berikut: 1) Pegeluaran untuk pelaksanaan pelajaran, 2) Pegeluaran untuk tata usaha sekolah, 3) Pemeliharaan sarana dan prasarana sekolah, 4) Kesejahteraan pegawai, 5) Pegeluaran untuk kegiatan siswa, 6) Pembinaan teknis edukasi, 7) Pegeluaran untuk pendataan.

Dari sekian sumber daya pendidikan yang dianggap penting adalah uang. Uang termasuk sumber daya yang langka dan terbatas. Untuk itu uang perlu dikelola dengan efektif dan efisien supaya membantu tercapainya tujuan pendidikan.

Sementara menurut Djamaluddin (1977: 11), anggaran adalah sejenis rencana yang menggambarkan rangkain tindakan atau kegiatan dalam bentuk angka-angka dari segi uang untuk jangka waktu tertentu (Uhar, 2013: 293-294 ). Anggaran memiliki dua sisi, yaitu sisi penerimaan dan sisi pengeluaran. Sisi penerimaan mengambarkan perolehan atau besarnya dana yang diterima oleh lembaga dari setiap sumber dana, misalnya dari pemerintah, dari orang tua peserta didik, dan sumber-sumber lainnya. Sedangkan sisi pengeluaran menggambarkan besarnya biaya yang harus dikeluarkan untuk tiap komponen program (Tim Dosen Administrasi UPI, 2015: 258).

Kata madrasah dalam bahasa Arab berarti tempat atau wahana untuk mengenyam proses pembelajaran (Nata 2004: 50). Dalam bahasa Indonesia madrasah disebut dengan sekolah yang berarti bangunan atau lembaga untuk belajar dan memberi pengajaran (Poerwadarminta 1984: 889). Madrasah adalah wadah atau tempat belajar ilmu-ilmu keislaman dan ilmu pengetahuan keahlian lainnya yang berkembang sesuai dengan zamannya. Maka istilah madrasah identik dengan pendidikan Islam, akan tetapi tidak sama dengan 'pendidikan agama Islam'. Dalam perkembangannya, madrasah berkedudukan sebagai lembaga pendidikan Islam yang mengombinasikan pendidikan keagamaan dengan pengajaran ilmu-ilmu umum (Irawan, 2016: 305).

Dalam sejarah pertumbuhan dan perkembangan di Indonesia ada dua momentum yang sangat menentukan eskistensi madrasah: pertama, SKB 3 Menteri 1975 yang menjadi pintu masuk madrasah sebagai salah satu lembaga pendidikan Islam yang setara dengan sekolah umum; kedua, UU Sisdiknas 
Nomor 2/1989 yang menjadikan madrasah bukan saja sebagai lembaga yang setara dengan pendidikan umum, lebih dari itu madrsah diakui sebagai sekolah umum berciri khas agama Islam (Kosim, 2007: 57).

Madrasah Tsanawiyah Pesantren Pembangunan, adalah salah satu lembaga pendidikan Islam dari Yayasan Kyai Haji Sufyan Tsauri yang didalamnya terdapat Pondok Pesantren Pembangunan Majenang dan Lembaga Pendidikan Islam lainnya seperti MI, dan MA Pesantren Pembangunan Majenang, Kab. Cilacap

Untuk meningkatkan kualitas manajemen keuangan madrasah maka dalam pembiayaan madrasah yang efektif harus memperhatikan prinsip manajemen pembiayaan pendidikan yaitu sebagai berikut: (1) Akuntabilitas (Accountability); (2) Transparan (Transparency); (3) Integritas (Integrity); (4) Konsistensi (Consistensy); (5) Efektif dan Efisien.

Sejarah berdirinya Madrasah Tsanawiyah Pesantren Pembangunan Majenang, Cilacap, Jawa Tengah tujuannya yaitu membantu warga yang kurang mampu untuk meneruskan dari pendidikan dasar ke pendidikan lanjutan tingkat pertama. Karena dinaungi oleh Yayasan K.H. Sufyan Tsauri yang memang sebelumnya sudah berdiri pesantren, maka mereka mendirikan pula lembaga pendidikan Islam yang mengkombinasikan pendidikan keagamaan dengan pengajaran ilmu-ilmu umum, supaya wawasan warga Desa Cibeunying Kec. Majenang lebih berwawasan.

Madrasah adalah wadah atau tempat belajar ilmu-ilmu keislaman dan ilmu pengetahuan keahlian lainnya yang berkembang sesuai dengan zamannya. Maka istilah madrasah identik dengan pendidikan Islam, akan tetapi tidak sama dengan 'pendidikan agama Islam'. Dalam perkembangannya, madrasah berkedudukan sebagai lembaga pendidikan Islam yang mengombinasikan pendidikan keagamaan dengan pengajaran ilmu-ilmu umum (Irawan, 2016: 305). Kemudian dalam UUD 1945 pasal 31 ayat 1 bahwa setiap warga negara berhak mendapat pendidikan.

\section{Pengaggaran Keuangan Madrasah Tsanawiyah Pesantren Pembangunan}

1. Mengidentifikasi Kegiatan dan Sumber yang Dinyatakan dalam Uang

Mengidentifikasi Sumber dan Kegiatan yang dinyatakan dalam uang di Madrasah Tsawaniyah Pesantren Pembangunan ini, yaitu bersatu padu dengan menyusun budgeting. Pada tahap ini Madrasah Tsanawiyah Pesantren Pembangunan membuat tim penyusun yang terdiri dari $\mathrm{H}$. Muhayat Js (Bendahara/Yayasan), Hartono S.Pd (Waka Sarpras), Achmad Kamil (Kepala Tata Usaha) dan Jaenudin (Komite/Tenaga Pendidik) (hasil penelitian hal. 64).

Komite Madrasah adalah lembaga mandiri yang beranggotakan orang tua/ wali murid peserta didik madrasah, komunitas madrasah, serta tokoh masyarakat yang peduli pendidikan madrasah (Keputusan Dirjen Pendidikan Islam No. 2913 Tahun 2005 tentang Petunjuk Teknis Struktur Organisasi dan Pengelolaan Dana Komite Madrasah). Komite Madrasah Tsanawiyah Pesantren Pembangunan beranggotakan Drs. Zainal Khudlori Rouf (Ketua Komite Madrasah/tokoh masyarakat), Haji Isroni (Anggota Komite Madrasah/Wali Murid), Haji Masin (Anggota Komite Madrasah/ Wali Murid), Haji Matuf (Anggota Komite Madrasah/ Wali Murid), Drs. Mudasir (Anggota Komite Madrasah/ Kepala Madrasah), H. Muhayat Js (Bendahara Komite/ Komunitas 
Madrasah), dan Jaenudin, S.Ag (Sekretaris Komite/ Komunitas Madrasah) (Catatan Lapangan 2.2.2.W.BU hal 110)

Penyusunan Rencana Kegiatan dan Anggaran Madrasah Tsanawiyah Pesantren Pembangunan Majenang, tidak melibatkan semua anggota komunitas sekolah, tetapi diwakilkan oleh tim penyusun yang berpengalaman dan beranggotakan tenaga pendidik dan kependidikan. Seperti bapak Hartono salah satu tenaga pendidik yang merangkap menjadi wakil ketua sarpras, bapak jaenudin dan muhayat tenaga pendidik yang merangkap menjadi pengurus komite madrasah di Madrasah Tsanawiyah Pesantren Pembangunan Majenang.

Rencana Anggaran Pendapatan dan Belanja Sekolah (RAPBS) berdasarkan pada rencana pengembangan sekolah dan merupakan bagian dari rencana operasional tahunan. RAPBS meliputi penganggaran untuk kegiatan pengajaran, materi kelas, pengembangan profesi guru, renovasi bangunan sekolah, pemeliharaan buku, meja dan kursi. Penyusunan RAPBS tersebut harus melibatkan kepala sekolah, guru, komite sekolah, staf TU dan komunitas sekolah. RAPBS perlu disusun pada setiap tahun ajaran sekolah dengan memastikan bahwa alokasi anggaran bisa memenuhi kebutuhan sekolah secara optimal (Ismaya, 2015: 143).

2. Menyusun Budgeting

Rencana Anggaran Pendapatan dan Belanja Madrasah (RAPBM) atau biasa disebut RKAM (Rencana Kegiatan dan Anggaran Keuangan Madrasah) di Madrasah Tsanawiyah Pesantren Pembangunan Majenang bahwa rencana anggaran disusun setiap tahun ajaran sekolah dan memastikan bahwa anggaran bisa memenuhi kebutuhan sekolah.

Pada prinsip penganggaran menurut Nanang Fattah (2016:54) yaitu Adanya pembagian wewenang dan tanggung jawab yang jelas dalam sistem manajemen dan organisasi; Adanya sistem akuntansi yang memadai dalam melaksanakan anggaran; Adanya penelitian dan analisi untuk menilai kinerja organisasi; dan Adanya dukungan dari pelaksana mulai tingkat atas sampai tingkat bawah.

Mengidentifikasi kegiatan-kegiatan yang akan dilakukan selama periode anggaran di Madrasah Tsanawiyah Pesantren Pembangunan yaitu menentukan kegiatan yang akan dilaksanakan tahun periode anggaran dengan menentukan volume kegiatan dan harga satuan tiap kegiatan kemudian ditentukan kedalam kategori tahunan atau bulanan. Contoh, kegiatan ekstrakurikuler pramuka akan dilaksanakan empat kali dalam satu tahun dengan tiap kegiatan dilaksanalan biaya yang dikeluarkan Rp. 2.500.000, maka harga satuan dikali dengan volume jumlah nya yaitu Rp.10.000.000 pertahun. (RAKM 2016/2017)

Mengidentifikasi sumber-sumber yang dinyatakan dalam uang, jasa, dan

barang di Madrasah Tsanawiyah Pesantren Pembangunan yaitu mengklasifikasikan rencana anggaran dengan sub kegiatan yang berbeda. Rencana yang sudah diklasifikasikan berdasarkan kegiatan, jasa dan barang pada RKAM yaitu (a) kegiatan pembelajaran dan eskul siswa, (b) ulangan dan ujian, (c) belanja ATK dan barang habis pakai (barang habis pakai dan ATK KBM, barang habis pakai dan ATK perkantoran, alat kebersihan kantor), (d) langganan daya dan jasa, (e) Belanja Honor yang terdiri dari Honor Tenaga Pendidik, Honor Pegawai Tenaga Kependidikan, tunjangan jabatan, tunjangan 
masa kerja, honor pembina ekstrakurikuler, tunjangan lauk pauk dan HR 13, (f) Biaya Rapat/perjalanan Dinas dan Pengembangan Tenaga Kependidikan, (g) Belanja rumah tangga, (h) makan dan minum harian guru, (i) PPDB dan Kesiswaan, (j) Pengembangan sylabus dan standar isi, (k) Pemeliharaan gedung dan persawatan sarana prasarana madrasah, (I) pembelian sarana pembelajaran dan $(m)$ pengadaan sarana prasarana (RAKM 2016/2017)

Pada Madrasah Tsanawiyah Pesantren Pembangunan ini hanya memiliki dua sumber dana yaitu dari pemerintah yang biasa disebut BOS dan Komite Madrasah yang biasa disebut sumbangan operasional pendidikan (SOP) dan infak jariyah (uang gedung) yang ditarik dari wali murid. Jumlah Sumbangan Operasional Pendidikan yang dibayarkan siswa kepada komite madrasah yaitu sebesar Rp.35.000, sedangkan infak jariyah yaitu, kelas tujuh membayar sebesar Rp. 350.000, kelas delapan membayar sebesar Rp. 225.000, dan kelas sembilan membayar Rp. 150.000 serta biaya les sebesar Rp. 175.000 (Surat Pemberitahuan Hasil Rapat Pleno 2016).

Madrasah Tsanawiyah Pesantren Pembangunan dalam memformulasikan anggaran dalam bentuk format yang mudah untuk dipahami oleh pembacanya yang disetujui oleh tim penyusun. Menurut Nanang Fattah (2012: 53) Anggaran program adalah bentuk anggaran yang dirancang untuk mengidentifikasi biaya setiap program. Perhitungan anggaran didasarkan pada perhitungan dari masing-masing jenis program. Pada format ini rencana Kegiatan Anggaran dan Keuangan Madrasah di MTs Pesantren Pembangunan Majenang merinci kebutuhan setiap program yang terdapat kolom rincian pengeluaran, untuk merinci setiap kebutuhan dari masing-masing program/kategorisasi, kolom satuan untuk menentukan jenis satuan (paket, bh, kegiatan, orang, liter, lembar, triwulan, pack, JTM, unit, rim, botol, kantong dan tahun), kolom volume yaitu jumlah satuan yang dibutuhkan, kolom harga satuan untuk menentukan harga tiap satuan, kolom jumlah yang terdiri dari bulan dan tahun yaitu untuk mentukan pelaksaan/ kebutuhan dalam satu tahun atau tiap bulan, kolom sumber anggaran yang terdiri dari BOS dan Komite untuk mengetahui dari mana sumber dana berasal, untuk kolom jumlah yaitu jumlah kebutuhan tiap sub kegiatan (RAKM 2016/2017, lampiran hal. 153-173)

Pada kolom sumber anggaran yaitu untuk membedakan alokasi sumber anggaran, supaya mempermudah mengetahui mata anggaran yang dibiayai oleh dana BOS, dan mata anggaran yang dibiayai oleh komite madrasah. Kemudian pada kolom rencana pengeluaran, di rinci lagi setiap sub anggaran supaya lebih jelas dan transparan untuk yang membaca Rencana Kegiatan dan Anggaran Madrasah MTs Pesantren Pembangunan Majenang. Selanjutnya jumlah perbulan dan pertahun untuk membedakan jangka waktu atau periode penggunaan anggaran pada kegiatan dilaksanakan, barang yang daipakai dan dibutuhkan dan jasa yang digunakan oleh Madrasah Tsanawiyah Pesantren Pembangunan Majenang.

Pada Laporan Pertanggungjawaban Sumbangan Operasional Pendidikan (SOP) tahun 2015/2016 MTs Pesantren Pembangunan Majenang, total sumber dana nya yaitu Rp. 930.693.986. Dari komite madrasah sebesar Rp 278.180.000 dan dari Pemerintah (BOS) sebesar Rp 652.513.986. Pada laporan pertanggungjawaban terdapat sisi pemasukan dan sisi pengeluaran, pada sisi pengeluaran jumlahnya lebih sedikit yang menjadikan saldo lebih. 
Selanjutnya saldo lebih tersebut digunakan untuk sumber dana tahun berikutnya.

Dari pembahasan sebelumnya tentang sumber dana Peraturan Pemerintah Republik Indonesia No. 48 Tahun 2008 tentang Pendanaan Pendidikan Pasal (51) dana pendidikan dapat bersumber dari: (a) Pemerintah (pusat dan daerah), (b) Peserta didik (orang tua atau wali murid), (c) Masyarakat / dunia usaha (d) Bantuan pihak asing yang tidak mengikat (hibah), dan (e) Swadana. Namun, pada Madrasah Tsanawiyah pesantren Pembangunan Majenang hanya memiliki dua sumber dana, yaitu pemerintah (BOS) dan Komite Madrasah (Peserta didik (SOP)).

Selanjutnya setelah membahas sumber dana yaitu membahas usulan persetujuan anggaran, yaitu setelah Madrasah Tsanawiyah Pesantren Pembangunan Majenang mengidentifikasi kegiatan dan sumber dana, kemudian menyetorkan usulan rencana anggaran kepada pihak yang berwenang. Disini pihak yang berwenang yaitu komite madrasah. Seperti yang dikatakan oleh bendahara madrasah pada saat wawancara:

"iya mba, jadi gini, kami merencanakan itu semua waka madrasah lah ya, terus diberikan kepada komite, lah komite itu yang ngundang wali murid buat rembugan kalau yang sekolah butuhhkan dananya segini-segini-segini, itu kan sudah tercantum di RKAM lah, kalau sudah disetujui juga sama kepala sekolah ya langsung itu kumpulan seluruh wali murid, sekolah hanya memfasilitasi lah ceritane, lah sing rembugan ya itu para wali murid sama komite, ya sebenarnya sih pas lagi rembugan tarik ulur juga mba antar komite lah, ada yang setuju ada yang tidak gitu lah, tapi kan sudah ada rincian kebutuhan di RKAM ya itu tinggal wali murid yang menentukan sendiri gitu"

Usulan rencana yang direncanakan diberitahukan kepada komite untuk meminta persetujuan, jika sudah mendapat persetujuan dari komite madrasah maka rencana anggaran baru bisa di usulkan kepada kepala madrasah untuk mendapat persetujuan melakukan musyawarah (rapat pleno) antara komite madrasah dan wali murid. Usulan RKAM tidak langsung ditanda tangan karena belum di setujui oleh semua pihak.

3. Merevisi Anggaran

Madrasah Tsanawiyah Pesantren Pembangunan belum pernah melakukan revisi anggaran. Hal tersebut karena, pada surat pemberitahuan hasil rapat pleno komite dan ulangan akhir semester gasal (UAS) menunjukan jumlah yang sama dengan jumlah iuran komite tiap bulan pada sub rincian pemasukan Rencana Kegiatan dan Anggaran Madrasah MTs Pesantren Pembangunan Majenang yaitu sebesar Rp. 35.000. Selanjutnya, pada Rencana Kegiatan dan Anggaran Madrasah sebelum dan sesudah disahkan, perubahannya hanya pada tanda tangan dan stempel.

4. Persetujuan Anggaran

Berdasarkan wawancara kepada Bapak $\mathrm{H}$ Muhayat Js bendahara Madrasah Tsanawiyah Pesantren Pembangunan mengatakan:

"persetujuan ya itu mba, tadi sebelum dirapatkan, RKAM di baca dulu sama kepala madrasah, kemudian kalau sudah setuju ya sudah tinggal dirapatkan bersama komite dan wali murid, nah itu yang disebut rapat pleno. 
Kan biar orang tua tau berapa-berapa biaya yang akan dikeluarkan dan untuk apa saja pengeluarannya selama periode anggaran"

Persetujuan anggaran di Madrasah Tsanawiyah Pesantren Pembangunan memiliki tiga tahap persetujuan. Yang pertama yaitu persetujuan dari tim penyusun dan komite madrasah, kemudian, persetujuan dari kepala madrasah untuk melakukan rapat pleno antara wali murid dan komite madrasah, ketiga yaitu persetujuan dari wali murid dengan menghasilkan keputusan pada surat pemeberitahuan hasil rapat pleno komite.

Persetujuan oleh tim penyusun dan komite madrasah dilakukan sebelum melakukan rapat pra pleno, pada saat rapat pra pleno tim penyusun dan komite madrasah bersama kepala madrasah MTs Pesantren Pembangunan Majenang membahas bersama Laporan Pertanggung Jawaban tahun sebelumnya yaitu tahun 2015/2016. Setelah membahas dan diterima serta di sahkan oleh kepala madrasah kemudian membahas Rencana Kegiatan dan Anggaran Madrasah Tsanawiyah Pesantren Pembangunan Majenang dan diterima, dengan hasil perbulan siswa membayar Rp.35.000 dan biaya les dan try out kelas sembilan sebesar Rp 175.000. Pada hasil penelitian tersebut, tertulis jumlah yang harus dibayarkan wali murid kepada komite madrasah, Rp. 35.000 perbulan, infak jariyah untuk kelas tujuh Rp 350.000, kelas delapan Rp 225.000, untuk kelas sembilan Rp. 150.000 dan biaya les try out kelas sembilan sebesar Rp. 175.000 .

5. Pengesahan Anggaran

Pengesahan anggaran di Madrasah Tsanawiyah Pesantren Pembangunan Majenang, disahkan oleh kepala madrasah setelah melalui beberapa prosedur yaitu setelah mendapatkan persetujuan dari komite madrasah, kepala madrasah, dan wali murid, maka selanjutnya kepala madrasah akan mengesahkan rencana anggaran keuangan madrasah. Pengesahan anggaran ini dibuktikan dengan adanya tanda tangan dari kepala madrasah dan stempel dari madrasah (RKAM, 2016/2017).

Menurut Muhaimin (2011: 202) tentang pengesahan anggaran yaitu, Setelah RKM selesai disusun oleh TPRKM, RKSM dibahas bersama oleh kepala sekolah, semua waka sekolah, semua guru, perwakilan TU, siswa, yayasan (jika ada) dan komite sekolah untuk dikaji ulang agar RKS yang telah disusun menjadi milik bersama dan sesuai dengan yang diharapkan. Selanjutnya RKS yang telah dikaji ulang dan diperbaiki disahkan oleh kepala sekolah/madrasah komite sekolah, dan Dinas Pendidikan Kab/Kota. Akhirnya RKS/M yang telah disahkan disosialisasikan kepada para pemangku kepentingan disekolah.

\section{Implementasi Prinsip Manajemen Keuangan pada Penganggaran Keuangan}

Untuk meningkatkan kualitas manajemen keuangan madrasah maka dalam pembiayaan madrasah yang efektif harus memperhatikan prinsip manajemen pembiayaan pendidikan yaitu sebagai berikut: (1) Akuntabilitas (Accountability); (2) Transparan (Transparency); (3) Integritas (Integrity); (4) Konsistensi (Consistensy); (5) Efektif dan Efisien

1. Akuntabilitas 
Akuntabilitas berarti penggunaan uang di madrasah dapat dipertanggungjawabkan sesuai dengan perencanaan yang telah ditetapkan (Ismaya, 2015: 137). Dalam prinsip akuntabilitas yaitu adanya transparansi, standar kinerja, dan adanya partisipasi salin menciptakan pelayanan yang sesuai. Madrasah Tsanawiyah Pesantren Pembangunan Majenang memiliki dokumen Rencana Kegiatan Anggaran Madrasah (RKAM), Laporan Pertanggungjawaban SOP, Surat undangan rapat pleno wali murid, surat hasil pleno bersama wali murid dan laporan pertanggung jawaban dana BOS.

2. Transparansi

Transparansi berarti adanya keterbukaan. Transaparasi di bidang pengelolaan adanya keterbukaan dalam mengelola suatu kegiatan. Di lembaga pendidikan, bidang pengelolaan keuangan yang transparan berarti adanya keterbukaan pengelolaan keuangan lembaga pendidikan, yaitu: keterbukaan sumber keuangan dan jumlahnya, rincian penggunaan, dan pertanggungjawabanya harus jelas sehinga bisa memudahkan pihak-pihak yang berkepentingan untuk mengetahuinya (Ismaya, 2 015: 137).

Madrasah Tsanawiyah Pesantren Pembangunan membagikan Laporan Pertanggung Jawaban 2015/2016 dan Rencana Kegiatan Anggaran Madrasah tahun 2016/2017 kepada wali murid yang datang pada saat musyawarah antara wali murid dan komite madrasah (Hasil Rapat Pleno Komite Madrasah, 2016 lampiran halaman 126)

3. Integritas

Integritas laporan keuangan adalah laporan keuangan yang menampilkan kondisi suatu perusahaan yang sebenarnya, tanpa ada yang ditutup-tutupi atau disembunyikan (Hardiningsih, 2010:65). Pada Laporan pertanggung jawaban Sumbangan Operasional Pendidikan (SOP) MTs Pesantren Pembangunan Majenang tahun pelajaran 201/2016, memiliki saldo lebih sebesar Rp. 11.019.000, saldo tersebut digunakan untuk tahun selanjutnya yang tertulis dalam rincian pemasukan Rencana Kegiatan dan Anggaran Madrasah tahun pelajaran 2016/2017 sebesar Rp.11.019.000.

4. Konsistensi

Sistem dan kebijakan pengelolaan keuangan di Madrasah Tsanawiyah Pesantren Pembangunan Majenang dilakukan secara konsisten dan tetap memperhatikan dinamika dan perubahan organisasi yang ada, selain itu disesuaikan juga dengan visi, misi dan tujuan madrasah yaitu berakhlak mulia, berpikir global bertindak lokal melalui keteladanan dan profeseionalisme.

Konsistensi yaitu sistem dan kebijakan keuangan dari organisasi harus konsisten dari waktu ke waktu. Ini tidak berarti bahwa sistem keuangan tidak boleh disesuaikan apabila terjadi perubahan di lembaga. Pengelolaan dana pendidikan harus dilakukan secara konsisten dengan tetap memperhatikan dinamika dan perubahan organisasi yang ada. Kosistensi ini juga disesuaikan dengan visi, misi dan tujuan lembaga pendidikan yang telah ditentukan (Jahari, 2013: 76)

5. Efektif dan Efisien

Efektif sering kali diartikan sebagai pencapaian tujuan yang telah ditetapkan. Garner (2004) mendefinisikan efektivitas lebih dalam lagi, karena sebenarnya efektivitas tidak berhenti sampai tujuan tercapai tetapi sampai pada kualitatif hasil yang dikaitkan dengan pencapaian visi lembaga. Pengelolaan 
keuangan dikatakan memenuhi prinsip efektivitas kalau kegiatan yang dilakukan dapat mengatur keuangan untuk membiayai aktivitas dalam rangka mencapai tujuan lembaga yang bersangkutan dan kualitatif outcomes-nya sesuai dengan rencana yang telah ditetapkan.

Madrasah Tsanawiyah Pesantren Pembangunan Majenang Cilacap mampu mengoptimalkan kegiatan secara optimal sesuai dengan tujuan pendidikan dan mampu mengoptimalkan kinerja karena dikerjakan oleh ahlinya atau sudah terbiasa menangani kegiatan.

\section{SIMPULAN}

Kepala madrasah adalah tokoh kunci penyelenggaraan pendidikan. Karena itu, sudah sewajarnya mereka berlaku sebagai pemimpin yang efektif yaitu yang memiliki kemampuan untuk mengawasi alokasi pengaggaran keuangan madrasah. Kepala madrasah harus memiliki visi manajerial dan kultural dalam mengelola dan menyusun anggaran keuangan madrasah. Visi tersebut kemudian didifusi dan didiseminasi kepada seluruh individu, kelompok dan komponen organisasi di dalam madrasah dalam rangka pengalokasian dana supaya terserap sesuai kebutuhan madrasah.

Berdasarkan penelitian penganggaran keuangan di Madrasah Tsanawiyah Pesantren Pembangunan Majenang, maka dapat ditarik kesimpulan bahwa Mengidentifikasi kegiatan dan sumber yang dinyatakan dalam uang bersatu padu dengan menyusun Budgeting. Menyusun Budgeting, Madrasah Tsanawiyah Pesantren Pembangunan Majenang melakukan identifikasi kegiatan, sumber, barang, dan jasa. Persetujuan Usulan anggaran di Madrasah Tsanawiyah Pesantren Pembangunan yaitu, pertama persetujuan dari tim penyusun, persetujuan dari komite madrasah, kemudian kepala madrasah untuk mendapat persetujuan melakukan musyawarah antara komite madrasah dan wali murid. Madrasah Tsanawiyah Pesantren Pembangunan Majenang belum pernah melakukan revisi ulang anggaran. Persetujuan anggaran di Madrasah Tsanawiyah Pesantren Pembangunan, prosedurnya yaitu setelah rapat pleno dengan wali murid dan menjadi anggaran anggaran bersama maka RKAM itu mendapat persetujuan bersama. Kepala madrasah adalah salah satu orang yang memiliki wewenang dalam mengesahkan Rencana Anggaran Keuangan Madrasah dengan tanda tangan dan stempel madrasah. Untuk implementasi prinsip manajemen keuangan dalam penganggaran keuangan madrasah menerapkan prinsip akuntabilitas, integritas, transparansi, konsistensi, efektif dan efisien.

\section{REFERENSI}

Akdon, Dedi, dkk. (2015). Manajemen Pembiayaan Pendidikan. Bandung: PT. Remaja Rosdakarya Offset.

Don R. Hansen \& Maryanne M. Mowen. 1999. Akuntansi Manajemen edisi 4 Jilid 1.Jakatrta: Penerbit Erlangga

Fahrurrozi. (2012). Manajemen Keuangan Madrasah. Dalam Media Pendidikan [online], Vol. XVII No. 22012 Tersedia: http://journal.uinsgd.ac.id/index.php/jpi/article/view/508

Fattah, Nanang. (2012). Ekonomi dan Pembiayaan Pendidikan. Bandung: PT. Remaja Rosdakarya Offset. 
Fattah, Nanang. (2016). Standar Biaya Pendidikan. Bandung: PT. Remaja Rosdakarya.

Irawan. 2016. Paradigma Keilmuan Manajemen Pendidikan Islam. Dalam Manageria: Jurnal Pendidikan Islam [online]. Vol. I No. 22016.

Ismaya, Bambang. (2015). Pengelolaan Pendidikan. Bandung: PT Refika Aditama.

Jaja Jahari \& Amirulloh Syarbini, (2013), Manajemen Madrasah Teori Strategi dan Implementasi. Bandung: PT. Remaja Rosdakarya.

Keputusan Direktur Jendral Pendidikan Islam Nomor 2913 tahun 2015 tentang Petunjuk Teknis Struktur Organisasi dan Pengelolaan Dana Komite Madrasah.

Komite Madrasah MTs Pesantren Pembangunan, 2016.

Laporan Pertanggungjawaban Sumbangan Operasional Pendidikan (SOP) MTs Pesantren Pembangunan Tahun Pelajaran 2015/2016.

Muhaimin, dkk. (2009). Manajemen Pendidikan: Aplikasinya Dalam Penyusunan Rencana Pengembangan Sekolah/ Madrasah. Jakarta: Kencana.

Muhammad Kosim, (2007), Madrasah di Indonesia, Jurnal Tadris [online], Vol 2 Nomor. 1.

Mulyasa. (2013). Menjadi Kepala Sekolah Profesional. Bandung: PT. RemajaRosdakarya.

Peraturan Mentri Pendidikan Nasional Nomor 19 Tahun 2007 tentang Standar Pengelolaan.

Profil Madrasah MTs Pesantren Pembangunan Majenang Jejak Langkah Madrasah, (Catatan 2007-2012) dan Profil Madrasah 2016

Rencana Kegiatan dan Anggaran Madrasah (RKAM) MTs Pesantren Pembangunan Majenang, Cilacap tahun 2015/2016.

Rencana Kegiatan dan Anggaran Madrasah (RKAM) MTs Pesantren Pembangunan Majenang, Cilacap tahun 2016/2017.

Rusdiana. (2015). Pengelolaan Keuangan Pendidikan. Bandung: CV Pustaka Setia.

Struktur Organisasi MTs Pesantren Pembangunan Majenang Tahun Pelajaran $2017 / 2018$.

Surat Pemberitahuan Hasil Rapat Pleno Komite dan Ulangan Akhir Semester Gasal (UAS), 2016.

Suharsaputra, Uhar. (2010). Administrasi Pendidikan. Bandung: PT Refika Aditama.

Suharsaputra, Uhar. (2013). Administrasi Pendidikan (edisi Revisi). Bandung: PT Refika Aditama

Surat Pemberitahuan Hasil Rapat Pleno Komite dan Ulangan Akhir Semester/ UAS, No. MTs.8/13/PP.00.5/118/2016

Surat Keputusan Ketua Yayasan Nomor: 024/YKST/KP.1/130/2003

Surat Keputusan Kepala MTs Pesantren Pembangunan Nomor: MTs.8/13/PP.00.5/058/2014

TIM Dosen Administrasi Pendidikan UPI. (2015). Manajemen Pendidikan. Bandung: Alfabeta. 